NBER WORKING PAPER SERIES

\title{
THE INCIDENCE OF THE CORPORATE INCOME TAX IS IRRELEVANT FOR ITS (BENEFIT-BASED) JUSTIFICATION
}

\author{
Simon M. Naitram \\ Matthew C. Weinzierl \\ Working Paper 29547 \\ http://www.nber.org/papers/w29547 \\ NATIONAL BUREAU OF ECONOMIC RESEARCH \\ 1050 Massachusetts Avenue \\ Cambridge, MA 02138 \\ December 2021
}

The authors wish to thank Alan Auerbach, Eric Bond, Mihir Desai, Dhammika Dharmapala, Louis Kaplow, Andreas Peichl, and participants at the National Tax Association's 113th Annual Conference on Taxation, the 77th Annual Congress of the International Institute of Public Finance, and the International Economic Association's Roundtable on "The Economics and Economic Policy of Corporation Tax" for helpful comments and discussion. The views expressed herein are those of the authors and do not necessarily reflect the views of the National Bureau of Economic Research.

NBER working papers are circulated for discussion and comment purposes. They have not been peer-reviewed or been subject to the review by the NBER Board of Directors that accompanies official NBER publications.

(C) 2021 by Simon M. Naitram and Matthew C. Weinzierl. All rights reserved. Short sections of text, not to exceed two paragraphs, may be quoted without explicit permission provided that full credit, including $\left({ }^{\circ}\right.$ notice, is given to the source. 
The Incidence of the Corporate Income Tax is Irrelevant for its (Benefit-Based) Justification Simon M. Naitram and Matthew C. Weinzierl

NBER Working Paper No. 29547

December 2021

JEL No. H21,H25,H41

\section{ABSTRACT}

Robust support for corporate income taxation is a puzzle for standard tax theory because the tax's incidence is uncertain and unreliable. We propose a resolution: if the corporate tax is seen as a benefit-based tax, its normative appeal depends on the correspondence between its incidence and that of the benefit which corporations derive from the state's activities. We show that a simple mechanism makes this correspondence exact—and the net incidence of the tax zero-when the tax base matches what we call the benefit base. As a result, the appeal of the corporate income tax is independent of incidence as conventionally understood.

Simon M. Naitram

The University of the West Indies

Cave Hill Campus, PO Box 64

Bridgetown BB11000

Barbados

simon.naitram@cavehill.uwi.edu

Matthew C. Weinzierl

Harvard Business School

277 Morgan

Soldiers Field

Boston, MA 02163

and NBER

mweinzierl@hbs.edu 


\section{Introduction}

The case for a corporate income tax in the standard modern optimal taxation framework ${ }^{1}$ depends entirely on a question which decades of research have left unanswered: Who bears the burden of paying it? While the typical modern corporate tax is officially levied on the returns to corporate capital, since at least Harberger (1962) it has been clear that capital may not bear the full burden of the tax, as responses to the tax induce changes in the equilibrium allocation of, and thus returns to, both capital and labor. These effects are difficult to measure in the short term and arguably impossible to measure in the (more important) long term. Empirical studies find a wide range of wage responses to a $1 \%$ increase in the corporate tax rate -approximately $0 \%$ to $-0.6 \%$-implying that labor could bear anywhere from $0 \%$ to more than $100 \%$ of the burden of the corporate tax (Knaisch and Pöschel, 2021). This uncertainty has caused significant disagreement among economists about the division of the burden of the tax (Fuchs et al., 1998), leading Clausing (2011) to conclude that "generations of corporate tax incidence models have failed to reach a clear consensus on this question, and empirical work in this area is sparse and suffers from essential limitations." As a result, the incidence of the corporate tax remains unresolved. ${ }^{2}$

Tax theorists have thus struggled to find a robust justification for the imposition of the corporate income tax. Critics of the tax have long argued that society would be better served by imposing taxes directly as desired on the shareholders, workers, or customers of corporationsrather than risk having the burden of the corporate tax fall on an unintended party. ${ }^{3}$ The shaky justification for the corporate income tax also makes it difficult to confidently propose policy reforms or evaluate existing policy using the standard framework.

It is a puzzle, then, that popular and policymaker support for the corporate income tax is persistent and widespread. Public opinion research from Gallup has shown that, since at least 2004, approximately two-thirds of Americans have consistently said corporations pay "too little" in taxes. ${ }^{4}$ The United States has had a corporate income tax for over a century, and the average rate among OECD countries in 2020 was 23.7 percent (all were at least 9.0 percent). ${ }^{5}$ Moreover, recent international policy initiatives have aimed to reduce corporate tax avoidance, deter the "race to the bottom" encouraged by tax havens, and set a floor on corporate income tax rates. Together, these opinions and choices strongly suggest that uncertainty over the incidence of the

\footnotetext{
${ }^{1}$ That framework, due to Ramsey (1927), Mirrlees (1971), Diamond and Mirrlees (1971), and others, is welfarist. See Kaplow (2008) for an overview and defense of its approach.

${ }^{2}$ Research on the incidence of the corporate income tax is characterised by Fullerton and Metcalf (2002). Auerbach (2006) and Gravelle (2010) provide excellent overviews of the literature. Despite the long line of work, uncertainty remains. Prior to 2012 the U.S. Congressional Budget Office (CBO) allocated the entire economic burden of the tax to capital owners; since 2012 it has begun to allocate 25 percent of the incidence to workers (CBO, 2012). The Joint Committee on Taxation (2011) allocates incidence similarly in the long run, but allocates $100 \%$ of incidence to capital in the short run. The U.S. Treasury Department allocates $18 \%$ to workers (Cronin et al., 2013).

${ }^{3}$ See, among others, Musgrave, 1959 p. 173.

${ }^{4}$ See Gallup Historical Trends (n.d.): https://news.gallup.com/poll/1714/taxes.aspx.

${ }^{5}$ Moreover, major middle-income countries such as Brazil, China, India, and Nigeria assess still greater rates. See https://stats.oecd.org/Index.aspx?DataSetCode=CTS_CIT.
} 
tax on corporate income is not deterring its supporters. Bird (1996) sums up this puzzle neatly:

In sharp contrast, recent events in many countries have once again demonstrated that the general public is almost equally unanimous in holding the opposite conclusion, namely, that corporate taxes are among the best of all taxes. It is, of course, easy for economists to demonstrate that these popular views must largely be wrong, since they are based on fundamentally unconvincing beliefs about the incidence of corporate taxes - and in fact, as already suggested, the inherent uncertainty about corporate tax incidence actually provides another reason for suggesting that there is no place for such taxes in a tax system concerned to achieve efficiency and equity.

To resolve this puzzle, we need a reason to prefer the taxation of the corporation-and its uncertain incidence - to the certain incidence of direct taxation of corporate stakeholders. As Bird suggests, it may be tempting to attribute public and policymaker support for the corporate tax to strong beliefs about its incidence, but its incidence can never be more sure than that of direct taxes on stakeholders. ${ }^{6}$ Administrative arguments can be marshalled, ${ }^{7}$ but they rely on substantial (and we think questionable, at least in countries with effective institutions of tax administration) pessimism toward our relative ability to enforce other aspects of tax policy. Moreover, such arguments can at most count against rather than explain away the risk of misplaced incidence; administrative ease does not prevent the tax's burden from falling where we do not intend.

In this paper, we propose a resolution to this puzzle that is both familiar and novel: if the corporate income tax is seen as a benefit-based $\operatorname{tax},{ }^{8}$ its appeal depends not on the incidence of the tax alone but, instead, on how closely the incidence of the tax corresponds to the incidence of the benefit from the activities of the state which corporations' legal status enables them to enjoy. According to this benefit-based view, the appeal of a properly designed corporate tax is independent of its incidence as normally understood. Instead, it is preferable to impose a tax directly on corporations, through which its burden will fall wherever-but precisely whereverbenefit accrues, rather than attempting to tax shareholders for benefit they may not enjoy.

Our proposed resolution is familiar because the benefit theory of taxation is far from new. In fact, it is perhaps the oldest principle of optimal taxation. ${ }^{9}$ It was explicitly cited as the basis of the U.S. corporate income tax at its birth in 1909. But the benefit-based view of taxation has

\footnotetext{
${ }^{6}$ At the other extreme, some may argue that the unclear incidence of the tax is the source of its support, as all taxpayers can simultaneously believe they do not bear its burden. Collective delusion on such a long-lasting and often-debated policy seems implausible, however, especially given the prominence of incidence-based arguments in the debate.

${ }^{7}$ There are three main administrative arguments for the existence of the corporate tax: first, to prevent income shifting between personal and corporate income; second, to prevent firms from hoarding profits to avoid dividend taxation; third, because it is easier to tax a firm's profits rather than to tax individual shareholders. This view of the corporate tax is advanced by OECD (2001), Mirrlees et al. (2011), McLure (1979), Gordon and MacKie-Mason (1995). Zucman (2014) and Bank (2001) suggest this was the original purpose for the imposition of the tax.

${ }^{8}$ Under the benefit theory of taxation, taxes are assessed according to the benefit taxpayers receive from the activities of the state (see Section 2).

${ }^{9}$ Musgrave (1959).
} 
fallen out of favor over the last century, and it is rarely used today in the context of national policy analysis. We attribute this shift to an unfortunate narrowing of the conception of benefitbased taxation. Encouragingly for our purposes in this paper, a broader, classical view retains a foothold in debates over interjurisdictional corporate tax competition, ${ }^{10}$ where the case has been made for taxing corporations due to their benefit from local public goods (Vogel, 1988a,b,c; Weinzierl, 2018a; Escribano, 2019). We provide a formalization of this classical view which applies within jurisdictions as well as across them.

Our proposed resolution is novel because at its heart lies a simple but (we believe) as-yetunappreciated mechanism: the relative elasticities among the parties to the corporate form determine both who bears the burden of the tax and who accrues the benefit of the state's activities. The corporate form brings with it privileges, including limited liability protection and access to liquid public equity markets. These privileges magnify the corporation's ability to benefit from the broad range of the state's activities. Which party to the corporate form benefits from that magnification will depend on the outside options available to them. For example, the more that shareholders in U.S. C-corporations find partnerships, LLCs, non-U.S. companies, personal consumption, and other possible destinations for their capital comparatively unattractive, the more those shareholders benefit from the C-corporate form and the more inelastically they will supply their capital to it. That increased inelasticity also implies - as is familiar from standard tax theory - that they will bear more of the burden of the tax on C-corporations. A properly designed corporate tax, from the benefit-based perspective, yields a tight correspondence between tax and benefit for each stakeholder of the corporation. ${ }^{11}$ Moreover, as we show below, this correspondence is exact if what we call the benefit base - namely, the manner in which corporations benefit from the state's activities - matches the tax base.

This brief paper proceeds as follows. In Section 2, we trace the history of benefit-based thinking in the development of the U.S. corporate income tax and address some of the (we believe mistaken) reasons for which its influence, especially as a normative principle, has waned. In Section 3, we introduce our baseline formalization of benefit-based corporate taxation. In Section 4 , we consider variations on this baseline setup to allow for heterogeneity in and alternative functional forms of benefit. We conclude in Section 5.

\section{The benefit-based view in the history of the U.S. corporate income tax}

The idea that corporations should be taxed based on the benefit they receive from the activities of the state can be traced back centuries. An illustrative example in the context of state-level

\footnotetext{
${ }^{10}$ Across cities, states, or countries.

${ }^{11}$ We do not attempt, in this paper, to characterize optimal benefit-based corporate income taxation, so as to focus on our results about its incidence. In a companion paper, Naitram and Weinzierl (2021), we use an approach to setting optimal benefit-based corporate income tax rates based on Lindahl (1919) which yields an efficiency condition relating the marginal benefit from public goods and the rate of tax.
} 
property taxation in the early United States is provided by Bank (2001, footnotes removed):

In Massachusetts, for example, a manufacturing corporation resisted the application of a tax assessed in 1817 for the support of the church parish in which the corporation's plant was located. The attorney for the corporation argued that because "corporations have no souls" for the parish to save, the tax cannot possibly apply to them. In rejecting this argument, the court not only noted that a tax is not like a fee that may be charged only to those who benefit from it, but it also pointed out that a corporation benefits just as much as an individual when its "[p]roperty is made more secure both by the education of children, and the religious and moral instruction of adults."

In the early nineteenth century, the benefit-based view of individual taxation was still dominant (Cooper, 1994). Thus, this Massachusetts court's benefit-based justification for a corporation paying (property) tax reflects the then-widespread practice of treating corporations as separate entities for tax purposes - for example if (but not only if) they enjoyed obvious special benefits and privileges from their official state or federal charters (Bank, 2001).

Benefit-based reasoning retained its prominence when the rising role of non-chartered, large corporations in the mid- and late-nineteenth century brought with it - as part of the Progressive Era movement toward a larger role for the state in the economy - the first U.S. federal taxes on corporate income. After two temporary impositions, a lasting corporate income tax was adopted in 1909. While a strong case can be made that the purpose of that tax was to reach shareholder wealth and counteract personal income tax avoidance (Bank, 2001), the explicit justification for it offered at the time by President Taft was as "an excise tax upon the privilege of doing business as an artificial entity and of freedom from a general partnership liability enjoyed by those who own the stock." Taft's explicitly benefit-based justification was useful in preventing charges of unconstitutionality, as the use of direct income taxes would have to wait until the passage of the Sixteenth Amendment in 1913 (Sutherland, 1940). But it also reflected the long tradition of seeing the special status of corporations - through the bestowing of charters, access to public equity markets, or protection from unlimited liability - as grounds for their taxation. In other words, while supporters drew on a set of justifications for the corporate income tax, the benefit-based view was an important element of that set.

A quarter century later, a benefit-based justification was behind the introduction of graduated rates on corporate income. As Sutherland (1940) wrote contemporaneously:

The Revenue Act of 1935 was passed in answer to a tax message from the President [Franklin D. Roosevelt] to Congress dated June 19, 1935, in which he contended that the advantages conferred by the government upon corporations increased in value as the size of the corporations increased, that the advantages gained by the large corporations engaged in interstate business were derived through the federal government chiefly and that the principle of taxation in accordance with ability to pay, as well as 
in accordance with benefits received, should apply to corporate taxation much as it had been applied to the individual income tax.

The U.S. corporate income tax has used graduated rates ever since.

\subsection{Recent skepticism of the benefit-based view}

Despite its past prominence, the benefit-based view has been dismissed over the last several decades as a way of understanding the modern corporate income tax. A particularly stark example is from McDonald (2016), writing about the proper interpretation of the 1909 statute: "The [benefit-based] argument was tenuous at the time. It should not even be raised now."

At the heart of this opposition lie two claims: first, the activities of the state from which corporations benefit cost too little to justify a substantial corporate income tax; second, those activities' effects extend too far beyond Schedule C corporations to justify a special tax on them. In particular, limited liability provisions and the permission of dispersed equity ownership cost the state little, at least in terms of direct expenditure, and the former extends to a variety of corporate forms.

These critiques reflect a particular - and we believe mistaken - view of benefit-based taxation in general (i.e., not just for taxing corporations) which has handicapped its acceptance for the last century. That view holds that the benefit being taxed comes from specific activities of the state which have a direct effect on the taxpayer. It arises naturally from a focus on the idea that benefit-based taxes are meant to charge a "price" for these specific public services which taxpayers are willing to pay, as in the marketplace for private services, and it suggests that a low cost of provision implies a low price. Justifying modern corporate income taxes as benefit-based taxes of this type would, for the reasons mentioned above, indeed be difficult.

But there exists an alternative, "classical" view (in the words of Musgrave, 1959) of benefitbased taxation - extending back to at least Smith (1776), present in Lindahl (1919), and more recently resuscitated by Cooper (1994), Stewart (2015), and Weinzierl (2017). This view holds that benefit for a given taxpayer - and thus the relevant "price" they would be willing to paycomes not from specific activities of the government, but from the way in which the state's full set of activities magnifies the taxpayer's economic capacity, or "ability". Note that this classical view, linking benefit to ability, is explicit in the Roosevelt quote above.

Under this classical view, the proper approach to benefit-based taxation is not to assign particular activities of the state to particular beneficiaries, but to use a measure of the benefit from the full set of the state's activities for each actor which best captures their effect on that actor. 


\subsection{An alternative, classical view of benefit-based corporate income taxation which addresses the skeptics}

In the case of the corporate tax, this classical view suggests seeing limited liability and dispersed equity ownership not as isolated activities of the state which benefit C-corporations but, instead, as the privileges through which a C-corporation's benefit from the state's broad activities is magnified. While passing the laws establishing these privileges may require little expenditure, their value to corporations relies on the maintenance of an entire economic society through a wide range of costly state activities. Establishing and enforcing the rule of law, preserving peace and political stability, regulating markets, and all other fundamental activities of the state are inseparable pieces of a whole, and corporations benefit from that whole.

Of course, corporations are not the only beneficiaries of those activities, but the privileges corporations enjoy - limited liability and dispersed equity ownership, in particular - offer corporations unique power to make use of them. These privileges are worth very little, after all, to corporations without a functioning marketplace. And they are of particular value to large corporations (or those who wish to become large, and thus choose C-status), explaining the differential tax treatment across corporate forms. ${ }^{12}$ Our analysis in Section 3 explores how to formalize this classical view of the corporate income tax.

Strikingly, and as noted above, benefit-based reasoning following this classical view has a prominent place in contemporary analysis of local public finance and international tax competition. Tiebout (1956) theory provides a direct connection between the holistic set of public goods offered by a local jurisdiction and the taxes assessed on its residents in exchange, and local property taxes are often seen as the paradigmatic example of benefit-based taxes. Similarly, debates over residence-based, source-based, and destination-based taxation of corporate income have often relied on benefit-based reasoning, focusing on which country's provision of public goods should be assigned the credit for supporting the company's returns (see Stewart, 2015). ${ }^{13}$

\subsection{Relationship to existing literature}

Our analysis is related to important previous contributions which consider public goods as intermediate goods or inputs into the production process (Kaizuka, 1965). These public inputs are often thought to be specific types of government spending, such as spending on public infrastructure or human capital investment. This literature has wrestled with the question of how a public input should enter the firm's production function ${ }^{14}$ and what the answer to that question implies

\footnotetext{
${ }^{12}$ At least in the US tax code, the judgment appears to have been made that the benefit from public goods for the parties to other corporate forms - S-corps, LLCs, partnerships, etc. - can be taxed directly on the incomes of owners, workers, and customers, rather than through the corporate form.

${ }^{13}$ To the extent that the activities of states support not just the management or production or sale of a firm's output, but all three, a mixture of bases would be justified as optimal under a benefit-based view. Ideally, the distribution of tax payments across residence, source, and destination would be proportional to the role each state's public goods played in facilitating the return to capital produced by the overall activity.

${ }^{14}$ See, for example, Hillman (1978); Manning and McMillan (1979); Feehan (1989).
} 
for the appropriate tax base.

Different views of this public input have led to different recommendations about what the base of taxation should be. Sandmo (1972) proposes a tax on profits, while Manning et al. (1985) and Feehan and Matsumoto (2000) propose broader factor taxation. More recently, Gugl and Zodrow $(2015,2019)$ and Matsumoto and Sugahara (2017) compare the efficiency of capital taxes and production taxes in the presence of a public input.

Our contribution to this literature is conceptual: rather than tying the corporate tax to how specific public goods benefit the taxed corporation, we tie it to how the privileges of the corporate form magnify the benefit of the full set of the state's activities for the taxed corporation.

\section{The net incidence of corporate tax and benefit}

In this section, we formalize a benefit-based approach to the corporate income tax. In our baseline setting, a function of public goods spending multiplies the returns to capital in the corporation's profit function of an otherwise-standard general equilibrium corporate tax incidence framework. The representative corporation's profit function is:

$$
\Pi=(1-\tau) g(G)[F(K, L)-w L]-r K,
$$

where $\Pi$ is after-tax profit, $\tau$ is the corporate tax rate on revenue less wage costs, and $g(G)$ is a function of public goods spending $G$ which multiplies and thus can magnify the returns to corporate capital. ${ }^{15}$ Those returns are $F(K, L)-w L$, where the corporation's production function $F(K, L)$ uses capital, $K$, and labor, $L$, as inputs. Labor earns the wage $w$ and capital earns the rate $r$. We assume perfect competition and production that is constant returns to scale in capital and labor, so economic profits are zero. Here we assume that capital costs are not deductible from the tax base, but we relax this assumption later.

The first order conditions for the corporation are:

$$
(1-\tau) g(G) F_{K}=r, \quad F_{L}=w .
$$

Note that under this specification of how benefit accrues to the firm, both the corporate tax and public goods alter the optimal choice of capital and do not alter the choice of labor. To be clear, however, this section's view does not forbid the assumption that public goods also affect the productivity of labor. Instead, it simply assumes that the intention of the corporate tax is to levy a tax on the benefit accruing to corporate capital. Other taxes not explicitly included in our analysis may be components of a comprehensive set of benefit-based taxes which address other channels of benefit. For example, the personal income tax may target the benefit accruing to

\footnotetext{
${ }^{15}$ This approach accords with the historical justifications for the tax reviewed above, namely that the capital owners who form and fund taxable corporations operate under a set of rules and regulations allowing them uniquely to magnify their capital's reach (and, they hope, return) throughout the economic system sustained by the state.
} 
labor and human capital in general, ${ }^{16}$ while value-added taxes may provide a way for the state to tax all parties (even exporters from abroad) who benefit from the support it provides for market transactions within its borders.

Given the assumption of constant returns to scale in production $F(K, L)$, we can write Euler's theorem as: $g(G) F(K, L)=\bar{r} K+w L$, where we define the term $\bar{r}=r /(1-\tau)$ as the corporation's tax-inclusive cost of capital. We define the share of output accruing to capital as $\alpha=(\bar{r} K) / F(K, L)$ and the share accruing to labor as $1-\alpha=(w L) / F(K, L)$. Differentiating and substituting in these factor shares and the first order conditions of the corporation yields:

$$
\alpha\left(\frac{g^{\prime}(G) d G}{g(G)}-\frac{d \tau}{1-\tau}\right)=g(G)(1-\alpha) \frac{d w}{w}+\alpha \frac{d r}{r}
$$

The corporation's elasticity of substitution is defined as $\sigma=\left(\frac{d K}{K}-\frac{d L}{L}\right) /\left[\frac{d w}{w}-\left(\frac{d \bar{r}}{\bar{r}}-\frac{g^{\prime}(G) d G}{g(G)}\right)\right]$.

We assume pared-down preferences for the capitalist and worker, with utility functions of the form: ${ }^{17}$

$$
u^{K}(K)=r K-\frac{K^{1+1 / e_{K}}}{1+1 / e_{K}}, \quad u^{L}(L)=w L-\frac{L^{1+1 / e_{L}}}{1+1 / e_{L}},
$$

where the terms $e_{K}$ and $e_{L}$ are the elasticities of capital and labor supply in the taxable corporate sector with respect to their respective payments within that sector. These utility functions show that capitalists and workers trade off the returns to supplying capital and labor in taxed corporations with the disutility from supplying them (i.e., in foregone outside options, such as supplying those factors to other types of corporations or using them for personal consumption or leisure).

While this form is familiar for the suppliers of labor, its use for suppliers of capital may be less so. In this context, it allows us to capture in a simple manner that capitalists could invest in non-corporate businesses, foreign corporations, or even personal consumption instead of in the corporations being taxed. Analytically, these forms cleanly deliver the elasticities of supply for both capital and labor which are critical to determining relative incidence.

The individuals' optimal choices of $K$ and $L$ are determined by the first order conditions $r^{e_{K}}=K$ and $w^{e_{L}}=L$. Fully differentiating these yields $e_{K} \frac{d r}{r}=\frac{d K}{K}$ and $e_{L} \frac{d w}{w}=\frac{d L}{L}$. These conditions allow us to simplify the definition for the corporation's elasticity of substitution in general equilibrium, yielding:

$$
\sigma\left(\frac{g^{\prime}(G) d G}{g(G)}-\frac{d \tau}{1-\tau}\right)=\left(e_{K}+\sigma\right) \frac{d r}{r}-\left(e_{L}+\sigma\right) \frac{d w}{w}
$$

\footnotetext{
${ }^{16}$ See Weinzierl (2018b) for an exploration of this idea.

${ }^{17}$ Used also by Saez and Zucman (2019) in their incidence analysis.
} 


\subsection{Net incidence results}

As described informally above, a corporate tax is a properly designed benefit-based tax if the incidence of the tax corresponds to the incidence of the benefit from the activities of the state. We now use equations 1 and 2 to obtain the relevant incidence results; that is, for changes in $r$ and $w$ due to changes in $\tau$ and $g(G)$.

We are particularly interested in the idea of net incidence, which we define as the combined effect on $r$ or $w$ of a joint policy change in both the corporate tax and spending on public goods. For brevity, we use the following notation: $\eta_{i, j}$ is the elasticity of $i$ with respect to $j$. For example, $\eta_{r, \tau}=\frac{d r}{r} / \frac{d \tau}{1-\tau}$ and $\eta_{r, G}=\frac{d r}{r} / \frac{g^{\prime}(G) d G}{g(G)}$ are the elasticities of the return to capital with respect to the corporate tax rate and the benefit from public goods, respectively. Using this notation, we can express net incidence generally as:

$$
\begin{gathered}
\frac{d r}{r}=\eta_{r, \tau} \frac{d \tau}{1-\tau}+\eta_{r, G} \frac{g^{\prime}(G) d G}{g(G)}, \\
\frac{d w}{w}=\eta_{w, \tau} \frac{d \tau}{1-\tau}+\eta_{w, G} \frac{g^{\prime}(G) d G}{g(G)},
\end{gathered}
$$

for capital and labor, respectively. It may be worth noting that standard modern optimal tax theory judges the corporate tax's appeal based on its direct incidence alone, namely the $d \tau /(1-\tau)$ terms, rather than on its net incidence as expressed here.

Since net incidence depends on the elasticities of the factor prices with respect to the policy changes, these elasticities determine the correspondence between the incidence of the tax and the incidence of the benefit. These elasticities can be expressed as:

$$
\begin{gathered}
\eta_{r, \tau}=-\frac{\alpha\left(e_{L}+\sigma\right)+(1-\alpha) \sigma g(G)}{\alpha\left(e_{L}+\sigma\right)+(1-\alpha)\left(e_{K}+\sigma\right) g(G)}, \quad \eta_{r, G}=\frac{\alpha\left(e_{L}+\sigma\right)+(1-\alpha) \sigma g(G)}{\alpha\left(e_{L}+\sigma\right)+(1-\alpha)\left(e_{K}+\sigma\right) g(G)} \\
\eta_{w, \tau}=-\frac{\alpha e_{K}}{\alpha\left(e_{L}+\sigma\right)+(1-\alpha)\left(e_{K}+\sigma\right) g(G)}, \quad \eta_{w, G}=\frac{\alpha e_{K}}{\alpha\left(e_{L}+\sigma\right)+(1-\alpha)\left(e_{K}+\sigma\right) g(G)}
\end{gathered}
$$

In these expressions, the signs on the right-hand sides indicate that - as expected-increases in the corporate tax tend to reduce returns to the factors of production while increases in public goods spending tend to raise them (all terms are individually non-negative).

These results reveal that a common mechanism is behind the incidence on the factors of production of both the tax and the benefit, a commonality which we believe is not widely appreciated. Note that, aside from their signs, the right-hand sides of these incidence expressions are identical within factors of production. The elasticities of capital and labor supply, in particular, enter in the same ways in the expressions for the incidence on each factor of both taxes and benefit.

For example, in the case of capital, we can see that as $e_{K} \rightarrow \infty, \eta_{r, \tau}$ and $\eta_{r, G}$ both shrink to zero, so that infinitely elastic capital bears no burden from the tax and enjoys no benefit from corporate privileges that magnify the effects of the state's activities on corporate profit. The former effect is familiar, but the latter reflects that infinitely elastic capital suppliers must be 
indifferent between - and thus obtain no particular benefit from - the corporate form versus other options for their capital. The same holds for labor, in expressions for $\eta_{w, \tau}$ and $\eta_{w, G}$, as $e_{L} \rightarrow \infty$. Away from these limit cases, the relative elasticities of capital and labor supply determine the shares of the burden and the benefit for capital and labor. The more elastic is capital supply relative to labor, the less of the burden capital bears and the less of the benefit it enjoys.

\subsection{Zero net incidence of the corporate tax}

We now use the expressions above to characterize the net incidence of the corporate tax in this baseline setting. The expressions for net incidence on capital and labor are, respectively:

$$
\begin{aligned}
& \frac{d r}{r}=\left(\frac{g^{\prime}(G) d G}{g(G)}-\frac{d \tau}{1-\tau}\right)\left(\frac{\alpha\left(e_{L}+\sigma\right)+(1-\alpha) \sigma g(G)}{\alpha\left(e_{L}+\sigma\right)+(1-\alpha)\left(e_{K}+\sigma\right) g(G)}\right) ; \\
& \frac{d w}{w}=\left(\frac{g^{\prime}(G) d G}{g(G)}-\frac{d \tau}{1-\tau}\right)\left(\frac{\alpha e_{K}}{\alpha\left(e_{L}+\sigma\right)+(1-\alpha)\left(e_{K}+\sigma\right) g(G)}\right) .
\end{aligned}
$$

The first term on the right-hand sides of these expressions shows immediately that the incidence of the benefit from public goods and the incidence of the corporate tax offset exactly for both capital and labor whenever the percentage change in the benefit due to the public good equals the percentage change in the tax. That is, if we consider a policy experiment in which $\frac{g^{\prime}(G) d G}{g(G)}=\frac{d \tau}{1-\tau}$, then we obtain that:

$$
\frac{d r}{r}=\frac{d w}{w}=0
$$

so that net incidence is zero for both capital and labor.

In other words, in this baseline case the incidence of the corporate tax increase precisely matches the incidence of the increase in the benefit of public goods to the corporation, on both capital and labor. ${ }^{18}$ The corporate tax is, in this setting, a properly designed benefit-based tax.

The mathematics behind this result are simple: such a match between tax and benefit incidence holds because the tax base is perfectly aligned with what we might call its "benefit base". The conceptual implication is, we would argue, nevertheless substantial: under this view, the direct incidence of the tax, as conventionally understood, is irrelevant for its justification.

\section{Extensions and alternative specifications}

The formalization just presented not only avoids the critiques of a narrower view of benefit-based taxation but also gives us the flexibility to extend the analysis in two ways. Each addresses a criticism of the benefit-based approach in the specific context of corporate income taxation and, in so doing, demonstrates its broader explanatory potential.

\footnotetext{
${ }^{18}$ This is analogous to what Kaplow (1996) describes as being the case where the "incidence of the tax adjustment matches the incidence of the benefits of the public good" (Kaplow, 1998).
} 


\subsection{Heterogeneity in benefit and variation in the tax base: an example with deductibility}

One critique of a benefit-based approach is that no simple corporate income tax can hope to match the heterogeneity with which different corporations benefit from the activities of the state. Benefit may vary in complex ways with firm size, sector, capital intensity, financial structure, exposure to liability through its operations, and more. How could a corporate income tax be subtle enough to accommodate all this variation? One response is that simplicity in a tax has its own value, such that matching benefit "on average" may be preferable to a more precise but cumbersome system. More conceptually interesting, while the statutory corporate income tax rate may be a blunt tool, the myriad subtleties of the corporate income tax system may be seen-with this benefitbased view in mind - as attempts to tailor the tax to how different corporations benefit from the state's activities. For example, multiple progressive marginal rates, industry-specific clauses, the asymmetric treatment of debt and equity financing, regulatory provisions, and partial and variable expensing of investment may be seen as additional tools within the broad corporate tax system that tailor its impact across these and other dimensions of heterogeneity. As an example, we now turn to exploring the last of these variations.

Most corporate tax systems around the world allow some portion of the cost of capital to be deducted from the corporate tax base, with that portion varying across industries, types of capital, and the business cycle. A benefit-based view suggests that these variations correspond to variations in how much the taxed corporation's return to capital is due to the state's activities. For example, greater deductibility implies less taxable benefit.

We generalize our results to the case of partially deductible investment costs. Let $\theta$ be the share of the cost of capital which can be deducted from the corporate tax base, where $0 \leq \theta \leq 1$. The corporation's first order condition with respect to capital becomes:

$$
g(G) F_{K}=\frac{(1-\theta \tau)}{(1-\tau)} r
$$

We can define $v$ as the marginal effective tax rate, where $(1-v)=(1-\tau) /(1-\theta \tau)$, and thus redefine the tax inclusive cost of capital to be $\hat{r}=r /(1-v)$.

Our preceding analysis can be directly extended to this case if tax policy changes are always thought of as changes in the effective tax rate $v$; that is, as a combination of changes in the corporate tax rate $\tau$, the deductibility of capital $\operatorname{costs} \theta$, or both. Then, our incidence and net incidence results can be readily used so long as they are understood in terms of this marginal effective tax rate rather than the statutory tax rate.

The policy pairing which would give a zero net incidence is now $\frac{g^{\prime}(G) d G}{g(G)}=\frac{d v}{1-v}$, a result which has at least two implications of interest. For a larger initial $\theta$ (that is, an increase in the deductibility of capital), a smaller increase in public goods spending offsets any given change to $\tau$. Intuitively, the larger $\theta$ makes the increase in the statutory rate $\tau$ less burdensome, so a smaller 
increase in public goods benefit is required to offset it. Second, an increase in $\tau$ and a decrease in $\theta$ both imply that a larger increase in public goods spending is required to offset the greater burden on corporations.

\subsection{Alternative benefit base specifications; an example of benefit through increased Hicks-Neutral productivity}

In addition to providing an explanation for heterogeneity in the corporate tax base, our formalization also allows us to analyze the incidence implications of alternative specifications of the benefit base - that is, of how the state's activities benefit corporations - given a statutory corporate tax base. We can therefore formalize the concerns of Devereux (2019) and Devereux et al. (2021), who ask whether the burden of the corporate tax aligns with the benefit from public goods. ${ }^{19}$

Before turning to an example, we note that one related and interesting implication of this analysis is that our benefit-based approach to incidence may help to explain why local and national governments experiment with changes to the corporate tax base. If the corporate tax is meant to tax the same income which is magnified by the corporation's privileged access to the benefits of the activities of the state, changes in how policymakers perceive those benefits accruing to corporations - changes to the "benefit base" - should translate into adjustments to the tax base. ${ }^{20}$ Examining early attempts to tax corporations in the nineteenth-century United States, we find substantial variation in how individual states defined the tax base; that variation may suggest that states were themselves trying to find the base which best corresponded to the benefit they were providing.

For example, consider an alternative formalization in which the benefit from the full set of state activities enters as a Hicks-neutral magnifier of corporate productivity. We believe this approach less precisely captures the specific benefit which the corporate tax intends to target than does our baseline case (where it enters as a magnifier of the returns to capital), but it will be a familiar and mathematically natural case for most readers. Moreover, its analysis will help to clarify the drivers of our main incidence results by showing how a mismatch between the way in which benefit accrues to the corporation and the corporate tax base typically generates non-zero net incidence.

In this case, the corporation's after-tax profit is:

$$
\Pi=(1-\tau)[g(G) F(K, L)-w L]-r K
$$

We assume production exhibits constant returns to scale in capital and labor, while government spending on public goods increases the marginal productivity of both capital and labor in similar

\footnotetext{
${ }^{19}$ See also Weichenrieder (2005) and De Mooij (2005).

${ }^{20}$ Schlunk (2002, pg. 364) notes that the under a benefit-based tax, the government should define the tax base (entity income) as whatever base it believes would best correlate with the benefits produced by the use of the corporate form.
} 
proportions. $^{21}$

For changes in $r$ and $w$ due to changes in $\tau$ and $g(G)$, and using our notation from before, the relevant incidence results are:

$$
\begin{array}{cl}
\eta_{r, \tau}=-\frac{\sigma+\alpha e_{L}}{(1-\alpha) e_{K}+\alpha e_{L}+\sigma}, & \eta_{r, G}=\frac{\sigma+e_{L}}{(1-\alpha) e_{K}+\alpha e_{L}+\sigma} \\
\eta_{w, \tau}=-\frac{\alpha e_{K}}{(1-\alpha) e_{K}+\alpha e_{L}+\sigma}, & \eta_{w, G}=\frac{\sigma+e_{K}}{(1-\alpha) e_{K}+\alpha e_{L}+\sigma} .
\end{array}
$$

As before, the signs on the right-hand sides of these expressions indicate that increases in the corporate tax tend to reduce returns to the factors of production while increases in public goods spending tend to raise them. However, contrary to our previous incidence result, the numerators of these expressions differ within each factor. This suggests that the mechanism which produced an exact correspondence under our previous formulation may not have the same effect under the Hicks-neutral benefit.

Under this setting, the incidence of the tax and of the benefit from public goods will, other than in special cases, only imperfectly correspond. For zero net incidence to hold, given expressions 8 and 9, the following conditions must hold for capital and labor, respectively:

$$
\begin{aligned}
& \left(\frac{\sigma+\alpha e_{L}}{(1-\alpha) e_{K}+\alpha e_{L}+\sigma}\right)\left(\frac{d \tau}{1-\tau}\right)=\left(\frac{\sigma+e_{L}}{(1-\alpha) e_{K}+\alpha e_{L}+\sigma}\right)\left(\frac{g^{\prime}(G) d G}{g(G)}\right), \\
& \left(\frac{\alpha e_{K}}{(1-\alpha) e_{K}+\alpha e_{L}+\sigma}\right)\left(\frac{d \tau}{1-\tau}\right)=\left(\frac{\sigma+e_{K}}{(1-\alpha) e_{K}+\alpha e_{L}+\sigma}\right)\left(\frac{g^{\prime}(G) d G}{g(G)}\right) .
\end{aligned}
$$

These expressions imply that, for $\alpha \in(0,1)$ and positive $\sigma, e_{L}$, and $e_{K}$, a policy experiment can have zero net incidence on both capital and labor in only three cases: namely if $e_{K} \rightarrow \infty$, $e_{L} \rightarrow \infty$, or $\sigma=0 .{ }^{22}$

When either elasticity of supply is very large, incidence of the tax and benefit are both shifted entirely to the other factor, and the tax and public spending changes can be scaled to offset each other on the less elastic factor. For example, if $e_{K} \rightarrow \infty$, then $\eta_{r, \tau}=0$ and $\eta_{r, G}=0$, while $\eta_{w, \tau}=-\frac{\alpha}{1-\alpha}$ and $\eta_{w, G}=\frac{1}{1-\alpha}$, so a policy in which $\frac{g^{\prime}(G) d G}{g(G)}=\alpha \frac{d \tau}{1-\tau}$ will have zero net incidence for both factors. Intuitively, the large elasticity of capital allows workers to capture the benefit from the state's activities just as it forces them to bear the burden of the tax. A similar story applies if $e_{L} \rightarrow \infty$.

If $\sigma=0$, the fixed proportions of capital and labor in production neutralize an asymmetry -in this section's setting - between the way in which the corporate tax and the benefit from public goods affect the corporation's choices. While the corporate tax is imposed only on the returns

\footnotetext{
${ }^{21}$ This approach is similar to Manning et al. (1985), Feehan (1998), Gugl and Zodrow (2019), among others, albeit for public inputs rather than the privileges of the corporate form.

${ }^{22}$ Outside of the three special cases, the ratio of the net incidence expressions can be written as: $\frac{d r / r}{d w / w}=-\left(\frac{1-\alpha}{\alpha}\right)$. In this case, the factor supply elasticities $e_{K}$ and $e_{L}$ do not matter for the relative changes in $r$ and $w$. Consider a simple example of how this works: when $\frac{g^{\prime}(G) d g}{g(G)}=\alpha \frac{d \tau}{1-\tau}$ and $\alpha=0.4$, the percentage change in $r$ is always -1.5 times the percentage change in $w$.
} 
to capital (i.e., because wages are expensed while the costs of capital are not), the Hicks-neutral $g(G)$ benefits both factors symmetrically. Only when $\sigma=0$, so that corporations must always scale capital and labor inputs in the same ratio, does this asymmetry not distort the incidence of

tax away from that of benefit. In particular, with $\sigma=0$ we can show that $\frac{\eta_{r, \tau}}{\eta_{w, \tau}}=\frac{e_{L}}{e_{K}}, \frac{\eta_{r, G}}{\eta_{w, G}}=\frac{e_{L}}{e_{K}}$, so that the relative incidence of the change in taxes and the change in benefit are both spread across capital and labor in inverse proportion to their relative elasticities of supply.

Positive $\sigma$ distorts this simple correspondence so that net incidence diverges from zero for both factors. Specifically, labor enjoys a positive net incidence while capital bears a negative net incidence, as $d w / w>0$ and $d r / r<0$. The magnitude of these deviations from zero net incidence are increasing in $\sigma$.

Thus, outside these three special cases, in this setting the asymmetry between how capital and labor are affected by tax and benefit can lead to non-zero net incidence. Recall from earlier that this non-zero net incidence does not arise when the tax base and the benefit base are aligned, as when benefit accrues as magnified returns to corporate capital in the context of a typical modern corporate tax.

\section{Conclusion}

This paper establishes something of a possibility result: the corporate income tax can be justified without regard to its direct incidence, if the objective of the tax system is to assess taxes based on the benefit taxpayers enjoy from the full set of the activities of the state. While the benefit theory of taxation has waxed and waned over time as a criterion of optimal taxation, it has held a place of prominence in reasoning over interjurisdictional corporate tax policy, and it had pride of place throughout the twentieth-century history of political rhetoric on corporate taxation in the United States. We re-introduce a classic approach to benefit-based taxation that addresses prominent past critiques and has particular resonance in the context of corporate income taxation.

This possible justification for the corporate income tax resolves the puzzling coexistence of irresolvable uncertainty over who bears its burden and persistent support for it among the public and policymakers. It can do so because it establishes a reason to prefer taxing corporations rather than the stakeholders of corporations directly. That is, the benefit-based logic for the corporate tax is built on the idea that the burden of the tax should fall most on those who benefit most from the corporate form, whether owners, workers, or customers. We show that such a correspondence between tax and benefit incidence can obtain, as both are determined by the same relative elasticities of supply for capital and labor. When the corporate tax base matches what we call the benefit base - namely, how corporations capture the benefit of the state's activities - this correspondence is exact and the corporate income tax is a properly designed benefit-based tax. 


\section{References}

Auerbach, Alan J, "Who bears the corporate tax? A review of what we know," Tax policy and the economy, 2006, 20, 1-40.

Bank, Steven A, "Entity Theory as Myth in the Origins of the Corporate Income Tax," Wm. \& Mary L. Rev., 2001, 43, 447.

Bird, Richard M, "Why tax corporations?," 1996.

CBO, "The Distribution of Household Income and Federal Taxes, 2008 and 2009," Technical Report, Congressional Budget Office 2012.

Clausing, Kimberly A, "In search of corporate tax incidence," Tax Law Review, 2011, 65, $433-472$.

Cooper, Graeme S, "The benefit theory of taxation," Austl. Tax F., 1994, 11, 397.

Cronin, Julie Anne, Emily Y Lin, Laura Power, and Michael Cooper, "Distributing the corporate income tax: Revised US treasury methodology," National Tax Journal, 2013, 66 (1), 239

Devereux, Michael P, "How Should Business Profit Be Taxed? Some Thoughts on Conceptual Developments During the Lifetime of the IFS*," Fiscal Studies, 12 2019, 40 (4), 591-619.

_, Alan J Auerbach, Michael Keen, and Wolfgang Schön, Taxing profit in a global economy, Oxford University Press, USA, 2021.

Diamond, Peter A and James A Mirrlees, "Optimal taxation and public production II: Tax rules," The American Economic Review, 1971, 61 (3), 261-278.

Escribano, Eva, Jurisdiction to Tax Corporate Income Pursuant to the Presumptive Benefit Principle: A Critical Analysis of Structural Paradigms Underlying Corporate Income Taxation and Proposals for Reform, Kluwer Law International BV, 2019.

Feehan, James, "Optimal Provision of Hicksian Public Inputs," Canadian Journal of Economics, 1998.

Feehan, James P, "Pareto-efficiency with three varieties of public input," Public Finance= Finances publiques, 1989, 44 (2), 237-248.

- and Mutsumi Matsumoto, "Productivity-enhancing public investment and benefit taxation: the case of factor-augmenting public inputs," Canadian Journal of Economics/Revue canadienne d'économique, 2000, 33 (1), 114-121. 
Fuchs, Victor R, Alan B Krueger, and James M Poterba, "Economists' views about parameters, values, and policies: Survey results in labor and public economics," Journal of Economic Literature, 1998, 36 (3), 1387-1425.

Fullerton, Don and Gilbert E Metcalf, "Tax incidence," Handbook of public economics, 2002, 4, 1787-1872.

Gallup Historical Trends, "Taxes."

Gordon, Roger $\mathbf{H}$ and Jeffrey $\mathbf{K}$ MacKie-Mason, "Why is there corporate taxation in a small open economy? The role of transfer pricing and income shifting," in "The effects of taxation on multinational corporations," University of Chicago Press, 1995, pp. 67-94.

Gravelle, Jennifer C, "Corporate tax incidence: review of general equilibrium estimates and analysis," 2010.

Gugl, Elisabeth and George R Zodrow, "Competition in business taxes and public services: are production-based taxes superior to capital taxes?," National Tax Journal, 2015, 68 (3S), 767.

_ and _ , "Tax competition and the efficiency of "benefit-related" business taxes," International Tax and Public Finance, 2019, 26 (3), 486-505.

Harberger, Arnold C, "The incidence of the corporation income tax," Journal of Political economy, 1962, 70 (3), 215-240.

Hillman, Arye L, "Symmetries and asymmetries between public input and public good equilibria," Public Finance= Finances publiques, 1978, 33 (3), 269-279.

Joint Committee on Taxation, "Present Law and Issues in U.S. Taxation of Cross-Border Income," 2011.

Kaizuka, Keimei, "Public goods and decentralization of production," The Review of Economics and Statistics, 1965, pp. 118-120.

Kaplow, Louis, "The optimal supply of public goods and the distortionary cost of taxation," National Tax Journal, 1996, pp. 513-533.

_ , "A note on the optimal supply of public goods and the distortionary cost of taxation," National Tax Journal, 1998, pp. 117-125.

- , The Theory of Taxation and Public Economics, stu - stud ed., Princeton, N.J.: Princeton University Press, 72008.

Knaisch, Jonas and Carla Pöschel, "Corporate Income Tax and Wages: A Meta-Regression Analysis," 2021. 
Lindahl, Erik, "Just Taxation - A Positive Solution," in Richard A Musgrave and Alan T Peacock, eds., Classics in the Theory of Public Finance, London: MacMillan, 1919, pp. 168176.

Manning, Richard and John McMillan, "Public intermediate goods, production possibilities, and international trade," Canadian Journal of Economics, 1979, pp. 243-257.

_, James R Markusen, and John McMillan, "Paying for public inputs," The American Economic Review, 1985, 75 (1), 235-238.

Matsumoto, Mutsumi and Kota Sugahara, "A note on production taxation and publicinput provision," The Annals of Regional Science, 2017, 59 (2), 419-426.

McDonald, John D, "A Taxing History," Taxes, 2016, 94, 93.

McLure, Charles E, Must Corporate Income be Taxed Twice?: A Report of a Conference Sponsored by the Fund for Public Research and the Brookings Institution, Vol. 10, Brookings Institution Press, 1979.

Mirrlees, James A, "An exploration in the theory of optimum income taxation," The review of economic studies, 1971, 38 (2), 175-208.

Mirrlees, James, Stuart Adam, Tim Besley, Richard Blundell, Stephen Bond, Robert Chote, Malcolm Gammie, Paul Johnson, Gareth Myles, and James Poterba, Tax by design: The Mirrlees Review, Vol. 2, Oxford University Press, 2011.

Mooij, Ruud A De, "Will corporate income taxation survive?," De Economist, 2005, 153 (3), $277-301$.

Musgrave, Richard A, The theory of public finance; a study in public economy, Kogakusha Co., 1959.

Naitram, Simon and Matthew Weinzierl, "An Optimal Benefit-Based Corporate Income Tax," 2021.

OECD, Corporate tax incentives for foreign direct investment, OECD Publishing, 2001.

Ramsey, Frank P, "A Contribution to the Theory of Taxation," The economic journal, 1927, $37(145), 47-61$.

Saez, Emmanuel and Gabriel Zucman, "Clarifying Distributional Tax Incidence: Who Pays Current Taxes vs. Tax Reform Analysis," 2019.

Sandmo, Agnar, "Optimality rules for the provision of collective factors of production," Journal of Public Economics, 1972, 1 (1), 149-157. 
Schlunk, Herwig J, "I Come Not to Praise the Corporate Income Tax, But to Save It," Tax L. Rev., 2002, 56, 329 .

Smith, Adam, An Inquiry into the Nature and Causes of the Wealth of Nations, London: W. Strahan and T. Cadell, 1776.

Stewart, Miranda, "The tax state, benefit and legitimacy," in Peter Harris and Dominic de Cogan, eds., Studies in the History of Tax Law, Volume 7, London: Hart Publishing, 2015, chapter 16 .

Sutherland, William A, "A Brief Description of Federal Taxes on Corporations Since 1861," Law and Contemporary Problems, 1940, 7 (2), 266-280.

Tiebout, Charles M, "A pure theory of local expenditures," Journal of political economy, 1956, 64 (5), 416-424.

Vogel, Klaus, "Worldwide vs. Source Taxation of Income-A Review and Re-Evaluation of Arguments (Part II)," Intertax, 1988, 16, 310.

_, "Worldwide vs. source taxation of income-A review and re-evaluation of arguments (Part III)," Intertax, 1988, 16, 393.

_ , "Worldwide vs. source taxation of income-A review and re-evaluation of arguments," Intertax, $1988,16(8 / 9)$.

Weichenrieder, Alfons J, "(Why) do we need corporate taxation?," 2005.

Weinzierl, Matthew, "Popular acceptance of inequality due to innate brute luck and support for classical benefit-based taxation," Journal of Public Economics, 2017, 155, 54-63.

_ , "Review of Global Tax Fairness, Thomas Pogge and Krishen Mehta, Editors," Journal of Economic Literature, 2018, 56 (2), 673-684.

_ , "Revisiting the Classical View of Benefit-based Taxation," The Economic Journal, 2018, 128 (612), F37-F64.

Zucman, Gabriel, "Taxing across borders: Tracking personal wealth and corporate profits," The Journal of Economic Perspectives, 2014, 28 (4), 121-148. 